Thorax (1974), 29, 495.

\title{
Cigarette smoking and irreversible airways obstruction in the West Indies
}

\author{
G. J . M I L L E R ${ }^{1}$ \\ Medical Research Council Epidemiology Unit and Department of Medicine, \\ University Hospital of the West Indies, Kingston, Jamaica
}

\begin{abstract}
Miller, G. J. (1974). Thorax, 495-504. Cigarette smoking and irreversible airways obstruction in the West Indies. Two communities, one in Jamaica and one in Guyana, have been surveyed in order to investigate the relationships between cigarette smoking, respiratory symptoms, and lung function in the West Indies. Cigarette consumption was less than that reported in the United Kingdom, particularly among women. Smoking was associated with cough, phlegm, increases in total lung capacity and residual volume, and reductions in $\mathrm{FEV} \%$, transfer coefficient (KCO), and alveolar capillary blood volume $(\mathrm{Vc})$. Vital capacity (VC) and the diffusion capacity of the alveolar membrane (Dm) were normal. After allowing for differences in age and tobacco consumption, less cough, phlegm, and airways obstruction occurred in the West Indies than has been reported in the United Kingdom.

Forty-seven patients in Jamaica with chronic obstructive lung disease were followed for three years. All except six female asthmatics were either current smokers or ex-smokers. Smoking in patients was associated with a similar but more severe pattern of lung disease to that found in survey subjects with, in addition, reductions in VC and $\mathrm{Dm}$. In the non-smoking asthmatics $\mathrm{Kco}, \mathrm{Dm}$, and Vc were normal. The lung function of these 47 patients was similar to that reported for UK patients even though both chronic bronchitis and hypercapnia were considerably less common in Jamaica. Emphysema was present in all six patients who died and came to necropsy.

It is suggested that in the West Indies emphysema contributes more than bronchitis to airways obstruction in smokers. There was also evidence that subjects of African origin were less susceptible to the emphysema-producing effect of cigarettes than were other ethnic groups.
\end{abstract}

In industrialized countries in the temperate zone, smokers as a group show an excess of chronic cough, phlegm, and breathlessness compared with non-smokers, together with some airways obstruction (Report of the Surgeon General, 1972). These clinical findings have been collectively referred to as either chronic obstructive bronchitis, or chronic non-specific lung disease, or chronic lung disease with airways obstruction. None of these terms implicates smoking because the same features are also associated with atmospheric pollution, a cold damp climate (especially fog), and some industrial hazards (Higgins and Cochrane, 1961; Holland and Reid, 1965), and the relative contributions of each of these factors towards the disease process remain uncertain.

'Present address: Medical Research"'Council Pneumoconiosis Unit, Llandough Hospital, Penarth, Glamorgan, S. Wales, UK
Of these four main contributory causes of chronic lung disease, only smoking exists to a significant extent in the West Indies. The climate is tropical with little seasonal variation in temperature. Air pollution is very low, even in the cities (Pan American Health Organization, 1971), and only a very few people are employed in industries with a known respiratory health risk. Previous to 1940 , the economy of the region was completely dominated by sugar and other forms of tropical agriculture. Today all territories are striving for industrial development and economic diversification. Trinidad has a large oil-refining industry, Jamaica and Guyana mine bauxite, and Jamaica also has a cement plant and a steel mill. Small industrial estates are emerging throughout the region but many of the industries are engaged only in component assembly or 'finishing touch' 
operations, and agriculture remains the major employer of labour.

In view of the healthy climate and atmosphere, Stuart and Hayes (1963) were surprised to discover that in Jamaica $14 \%$ of large hearts at necropsy showed right ventricular enlargement secondary to lung disease. Subsequently, Hayes and Summerell (1969) found that severe destructive emphysema was present in about $2 \%$ of men and $1 \%$ of women at necropsy. In the temperate zone countries the great majority of patients with emphysema smoke cigarettes, have chronic obstructive bronchitis, and also have a reduced transfer factor (diffusing capacity of the lung) (Burrows, Niden, Fletcher, and Jones, 1964). To determine whether this is also the case in tropical non-industrialized areas the inter-relationships between cigarette smoking, bronchitis, lung function, and necropsy findings have been studied in the West Indies and compared with those reported for the United Kingdom.

\section{SUBJECTS, PATIENTS, AND METHODS}

Most of the information about tobacco smoking and its effects on the lungs was collected during two community surveys, one in Jamaica (1969-70) and the other in Guyana (1968). The results have been compared with surveys of tobacco smoking (Tobacco Research Council, 1969) and of respiratory symptoms and lung function undertaken in the United Kingdom between 1966 and 1968 (Higgins et al., 1968).

In Jamaica an age-stratified random sample was taken of all men and women between 16 and 65 years of age living in a non-industrialized suburban community of the capital, Kingston. In Guyana, all men and women between 35 and 54 years, living in two adjacent rural villages, were asked to collaborate. In all, 409 subjects in Jamaica and 860 subjects in Guyana were interviewed, giving response rates of about $82 \%$ in both communities. Smoking habits were analysed for each of these groups. For the further analysis all subjects who either were less than 25 years, or were not predominantly of either African ${ }^{1}$ or Indian ${ }^{2}$ origin, or had some other condition likely to influence lung function (for example, pregnancy, inaptitude for the test) were excluded, as also were the few ex-smokers and smokers who did not use cigarettes. The numbers of respondents used in the analysis, by sex and ethnic composition, are presented in Table I. The ratio of Africans and Indians in the two samples differed markedly but did reflect the general composition of the populations from which they were drawn. Thus nearly all the Indians lived in Guyana, while Africans were well represented in both communities.

${ }^{1}$ People whose ancestors were brought to the West Indies from the west coast of Africa, hereafter referred to as Africans

'The descendants of immigrants brought from India, hereafter referred to as Indians

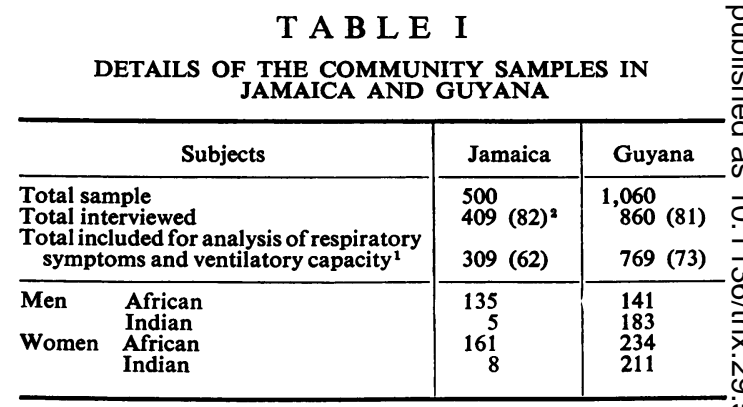

'See 'Subjects, patients, and methods' in text for criteria for inclusion. ${ }^{2}$ Figures in parentheses are percentages of total sample.

The methods used have been described elsewhere $\stackrel{\circ}{\longrightarrow}$ (Miller and Ashcroft, 1971; Miller et al., 1972). $\overrightarrow{c s}$ Subjects answered a questionnaire for occupation and $\mathbb{D}$ medical history and a modified form of the Medical $\overrightarrow{\mathbb{D}}$ Research Council's questionnaire for respiratory 3 symptoms (1966). 'Chronic phlegm' was defined as production of phlegm on most days for three consecutive months of the year. Height and weight were $\vec{\theta}$ recorded and the forced expiratory volume in one $\rightarrow$ second $\left(F^{2} V_{1}\right)$ and forced vital capacity (FVC) were 0 measured with a dry spirometer (Collins, McDermott, and McDermott, 1964). The relationship between smoking and the FEV ${ }_{1}$, expressed as a percentage of FVC (FEV\%), was then compared in the Caribbean $\frac{0}{\varnothing}$ and UK communities. Irreversible airways obstruction 2 was defined as an FEV\% of 65 or less which did not $\overrightarrow{0}$ increase to above 65 when measured again 10 minutes 3 after $1 \%$ isoprenaline sulphate inhalation. The justification for this procedure is discussed later.

In Jamaica, a random sub-sample of 60 men and 60 women, and all subjects not in the sub-sample buto who were found to have irreversible airways obstruc-0 tion as defined (16 men and 5 women), were asked to return for lung volume and gas transfer studies. In 3 all, $104(73 \%)$ subjects collaborated. Total lung capacity and its subdivisions were measured by helium dilution with a spirometer. The single breath carbon monoxide transfer factor (TF) and its two components, the diffusing capacity of the alveolap membrane $(\mathrm{Dm})$ and the alveolar capillary bloote volume ( $\mathrm{Vc}$ ), were estimated with a semi-automated apparatus (Resparameter-Meade et al., 1965) byos measuring TF at high and normal alveolar oxygen 0 tensions (cf Cotes, 1968). All subjects were asked ton refrain from smoking from the previous evening, and $\omega$ each breathed oxygen for 10 minutes before the studye to ensure that the carbon monoxide back pressure wase as low as possible. The transfer factor was calculated at an alveolar volume obtained by summing the volume of the single breath and the residual volume measured by helium dilution (Ogilvie, Forster? Blakemore, and Morton, 1957). In a few subjects the measured gas transfer indices were adjusted tod correct for the effects of anaemia (Cotes et al., 1972)응 After excluding some subjects for the reasons given 
earlier, the data for nine male and 31 female nonsmokers, and for 36 male and six female current smokers were accepted for analysis (58\% of total sample).

The Jamaica survey was complemented by a clinical study of all available patients ( 36 men and 11 women) with irreversible airways obstruction who were attending the University Hospital in Kingston. The patients were studied when their condition was stable in the same manner as the survey subjects with, in addition, measurement of the volume of sputum within the first hour after rising, a representative electrocardiogram, postero-anterior and lateral chest radiographs, and mixed venous $\mathbf{P C O}_{2}$ estimated by the method of Campbell and Howell (1962). Incomplete data were obtained for one man with familial emphysema, and a further patient was excluded because he was the only man of Chinese descent in the series, leaving the results of 45 patients for further analysis. When possible a necropsy examination was performed on those who died before the end of the study in March 1971.

\section{RESULTS}

Table II presents the prevalence rates of cigarette smoking ${ }^{1}$ by sex, age, and level of consumption in Jamaica and compares them with figures published for the UK in 1968 (Tobacco Research Council, 1969). In the UK about $55 \%$ of men at all ages from 16 to 59 years smoked cigarettes whereas in Jamaica comparable rates were not achieved until after 20 years. Unexpectedly, however, the highest prevalence rate $(71 \%)$ was found among Jamaican men aged 20-34 years. Overall about $36 \%$ of the UK men were heavy smokers (15 or more daily), compared with only $20 \%$ of Jamaican men. This difference between the two communities applied to all ages up to 60 years, after which the UK consumption pattern resembled that in Jamaica.

${ }^{1}$ Current cigarette smokers with or without other methods of tobacco smoking
Only $14 \%$ of women in the Jamaican survey and less than $10 \%$ of those below 35 years of age were cigarette smokers. In comparison, in the UK $45 \%$ to $50 \%$ of women of all ages between 16 and 59 years had acquired the habit. For heavy smoking the difference in prevalence rates was even greater, only $1 \%$ in Jamaica compared with $17 \%$ in the UK.

Fewer men and women smoked in Guyana than in Jamaica. Thus $48 \%$ of men and $4 \%$ of women in the Guyana survey smoked cigarettes, and only $11 \%$ of men and none of the women were heavy smokers.

Since few women in the West Indian surveys smoked, the further analysis concerning the effects of cigarettes was confined to the data for men. Table III presents the prevalence of chronic cough and chronic phlegm in men in the West Indies (Jamaica and Guyana combined) according to age group, ethnic group, and smoking category. The Figure shows the mean FEV\% values for these men, also by age and smoking category. In addition, Table III and the Figure present equivalent data for a random sample of men in Staveley, an industrial town in Derbyshire, England, which was surveyed in 1966 (Higgins et al., 1968). They show that in both communities symptom rates increased and average $\mathrm{FEV} \%$ declined with increasing age in all smoking categories with the possible exception of West Indian non-smokers. African nonsmokers in the West Indies were distinctive in showing no obvious increase in symptom rates and no more than a trivial decline $(1.4 \%$ over 20 years) in average $\mathrm{FEV} \%$ with increasing age. Within each age group symptom rates were increased and average $\mathrm{FEV} \%$ was decreased in smokers compared with non-smokers in both communities (except for FEV\% in younger heavy smokers in the Caribbean), but when standardized

T A B L E I I

PREVALENCE OF CURRENT MANUFACTURED-CIGARETTE SMOKING BY AGE GROUP AND LEVEL OF CONSUMPTION IN JAMAICA ${ }^{1}$ AND IN THE UK ${ }^{2}$

\begin{tabular}{|c|c|c|c|c|c|c|c|c|c|c|c|c|}
\hline \multirow{3}{*}{$\begin{array}{c}\text { Age Group } \\
\text { (yr) }\end{array}$} & \multicolumn{6}{|c|}{ Men } & \multicolumn{6}{|c|}{ Women } \\
\hline & \multicolumn{3}{|c|}{ Jamaica } & \multicolumn{3}{|c|}{ UK } & \multicolumn{3}{|c|}{ Jamaica } & \multicolumn{3}{|c|}{ UK } \\
\hline & $1-14$ & $15+$ & All & $1-14$ & $15+$ & All & $1-14$ & $15+$ & All & $1-14$ & $15+$ & All \\
\hline $\begin{array}{l}16-19 \\
20-34 \\
35-59 \\
60+ \\
\text { All ages }\end{array}$ & $\begin{array}{l}13 \cdot 0 \\
45 \cdot 8 \\
42 \cdot 6 \\
20 \cdot 0 \\
36 \cdot 4\end{array}$ & $\begin{array}{r}8 \cdot 7 \\
25 \cdot 0 \\
15 \cdot 8 \\
25 \cdot 0 \\
19 \cdot 7\end{array}$ & $\begin{array}{l}21 \cdot 7 \\
70 \cdot 8 \\
58 \cdot 4 \\
45 \cdot 0 \\
56 \cdot 1\end{array}$ & $\begin{array}{l}25 \cdot 8 \\
17 \cdot 7 \\
16 \cdot 4 \\
24 \cdot 9 \\
19 \cdot 3\end{array}$ & $\begin{array}{l}29 \cdot 5 \\
39 \cdot 5 \\
41 \cdot 0 \\
21 \cdot 6 \\
35 \cdot 6\end{array}$ & $\begin{array}{l}55 \cdot 3 \\
57 \cdot 2 \\
57 \cdot 4 \\
46 \cdot 5 \\
54 \cdot 9\end{array}$ & $\begin{array}{c}0 \\
7 \cdot 5 \\
15 \cdot 6 \\
16 \cdot 7 \\
12 \cdot 7\end{array}$ & $\begin{array}{l}0 \\
0 \\
3 \cdot 1 \\
0 \\
1 \cdot 2\end{array}$ & $\begin{array}{c}0 \\
7 \cdot 5 \\
18 \cdot 8 \\
16 \cdot 7 \\
13 \cdot 9\end{array}$ & $\begin{array}{l}33 \cdot 5 \\
27 \cdot 4 \\
29 \cdot 4 \\
17 \cdot 6 \\
25 \cdot 9\end{array}$ & $\begin{array}{r}12 \cdot 6 \\
21 \cdot 8 \\
22 \cdot 1 \\
6 \cdot 1 \\
16 \cdot 9\end{array}$ & $\begin{array}{l}46 \cdot 0 \\
49 \cdot 2 \\
51 \cdot 4 \\
23 \cdot 8 \\
42 \cdot 8\end{array}$ \\
\hline
\end{tabular}

Values are percentages based on the total number of subjects in each age group.

All 409 subjects who were interviewed.

Tobacco Research Council (1969).

-Adjusted to the UK age distribution. 
T A B L E I I I

PREVALENCE RATES (AS PERCENTAGE) OF CHRONIC COUGH (C) AND CHRONIC PHLEGM (P) 1 AMONG MEN IN THE WEST INDIES AND IN STAVELEY, UK², ACCORDING TO AGE GROUP AND SMOKING CATEGORY, 1966-68

\begin{tabular}{|c|c|c|c|c|c|c|c|c|c|c|c|c|c|c|c|c|c|c|}
\hline & & & & & & & \multicolumn{12}{|c|}{ Cigarette Smoker ${ }^{3}$} \\
\hline & \multicolumn{6}{|c|}{ Non-smoker } & \multicolumn{6}{|c|}{ Less than 15 per Day } & \multicolumn{6}{|c|}{15 or more per Day } \\
\hline & \multicolumn{2}{|c|}{$25-34$} & \multicolumn{2}{|c|}{$35-54$} & \multicolumn{2}{|c|}{$55-64$} & \multicolumn{2}{|c|}{$25-34$} & \multicolumn{2}{|c|}{$35-54$} & \multicolumn{2}{|c|}{$55-64$} & \multicolumn{2}{|c|}{$25-34$} & \multicolumn{2}{|c|}{$35-54$} & \multicolumn{2}{|c|}{$55-64$} \\
\hline & $\mathbf{C}$ & $\mathbf{P}$ & C & $\mathbf{P}$ & $\mathbf{C}$ & $\mathbf{P}$ & $\mathrm{C}$ & $\mathbf{P}$ & C & $\mathbf{P}$ & C & $\mathbf{P}$ & $\mathbf{C}$ & $\mathbf{P}$ & C & $\mathbf{P}$ & C & $\mathbf{P}$ \\
\hline $\begin{array}{l}\text { West Indies: } \\
\text { African } \\
\text { Indian } \\
\text { United }\end{array}$ & $\mathbf{0}$ & $\mathbf{0}$ & $\begin{array}{l}4 \\
5\end{array}$ & $\begin{array}{l}1 \\
2\end{array}$ & 0 & 0 & 0 & $\mathbf{0}$ & $\begin{array}{r}3 \\
20\end{array}$ & $\begin{array}{r}2 \\
16\end{array}$ & 13 & 13 & 0 & 0 & $\begin{array}{l}11 \\
22\end{array}$ & $\begin{array}{r}4 \\
22\end{array}$ & 50 & 25 \\
\hline Kingdom & 9 & 17 & 14 & 23 & 30 & 50 & 21 & 33 & 47 & 43 & 50 & 50 & 50 & 48 & 62 & 60 & 73 & 67 \\
\hline
\end{tabular}

${ }^{1}$ Chronic cough is defined as a positive response to question 5 , and chronic phlegm as a positive response to question 10 , in the Medical Research $c$ Council questionnaire for respiratory symptoms (1966).

'Higgins et al. (1968).

${ }^{3}$ Refers to men who are current smokers of cigarettes only (i.e. mixed smokers and ex-smokers excluded).

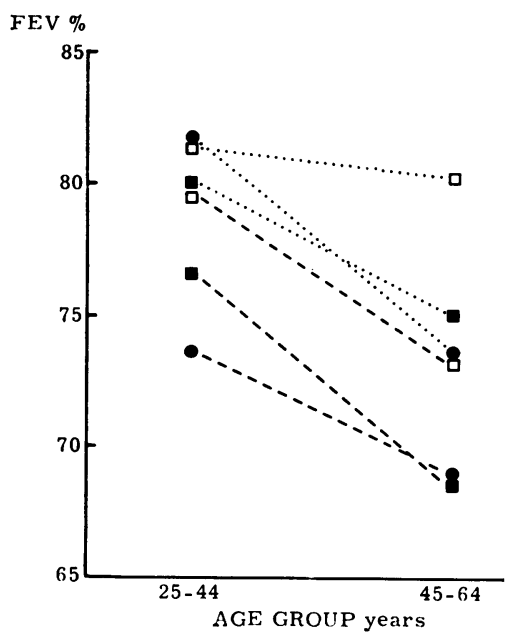

Figure. Mean FEV \% for men in the West Indies (.....) and in Staveley, UK (-.-) (Higgins et al., 1968) according to age and cigarette consumption: $\square$ non-smoker; $\square$ less than 15 cigarettes daily; 15 or more cigarettes daily.

for age and smoking habits, symptom rates were higher and mean FEV\% was lower in Staveley than in Jamaica and Guyana. Indian smokers in the West Indies had higher symptom rates and on average a $3 \%$ greater reduction in $\mathrm{FEV} \%$ than African smokers (not shown in the Figure). There were 20 African men (all Jamaican) and eight Indian men (one Jamaican) with irreversible airways obstruction as defined. Of these, 26 were current smokers and two were ex-smokers, and 20 were over 45 years of age.

Table IV presents the lung volumes and gas transfer indices for male non-smokers and current smokers in Jamaica. The smokers have been subdivided into those with $\mathrm{FEV} \%$ values greater $\frac{\mathbb{D}}{0}$ than 65 and those with values of 65 or less. Where $\mathbb{\mathbb { D }}$ the partial regression coefficients on age and height were statistically significant, the indices $\stackrel{\mathbb{S}}{-}$ have been standardized to the mean age and $\overrightarrow{0}$ height of smokers with an FEV \% greater than 65. Although none of the differences between the 0 groups achieved statistical significance some trends were clear. Total lung capacity, expiratory reserve volume, and residual volume were on average larger in smokers than in non-smokers, $\stackrel{D}{D}$ but vital capacity was similar in both groups. The lung volume changes were more obvious in smokers with airways obstruction. The partial $\frac{3}{\partial}$ regression coefficient on age for residual volume was only $+0.0031 . \mathrm{yr}^{-1}$ in non-smokers and not statistically significant, while that for smokers with an FEV \% of 70 and above was $+0.0211 . \mathrm{yr}^{-1} \stackrel{2}{\stackrel{2}{\Perp}}$ and significant. Similarly, the age coefficient for $\dot{\sigma}$ expiratory reserve volume was $-0.0031 . \mathrm{yr}^{-1}$ in non-smokers (not significant) compared with 8 $+0.0281 . \mathrm{yr}^{-1}$ in smokers with an FEV \% of $70 ₹$ or above (significant).

The average transfer factor of smokers with $\underset{D}{D}$ airways obstruction was $15 \%$ less than that of the other two groups. When allowance was made N for differences in alveolar volume (VA) between the groups by expressing the tranfer factor (TF) as the transfer coefficient (TF/VA), the trend to $\mathrm{\omega}$ decreasing gas transfer in smokers became more apparent. This reduction of gas transfer inco smokers was not due to any impairment of the diffusing capacity of the alveolar membrane, $?$ which showed the expected increase with increas- $T$ ing lung volumes, but rather was due entirely to a reduction in the alveolar capillary blood volume.

Symptom rates among women were similar to those among non-smoking men. Thus only $23 \%$ 
T A B L E I V

MEAN VALUES FOR LUNG VOLUME AND GAS TRANSFER INDICES IN MALE NON-SMOKERS AND CIGARETTE SMOKERS IN JAMAICA, ACCORDING TO SMOKING CATEGORY AND FEV\%

\begin{tabular}{|c|c|c|c|}
\hline \multirow[b]{2}{*}{ Index } & \multirow[b]{2}{*}{ Non-smokers (9) } & \multicolumn{2}{|c|}{ Cigarette Smokers } \\
\hline & & FEV $\%>65(23)$ & FEV $\% \leqslant 65(13)$ \\
\hline 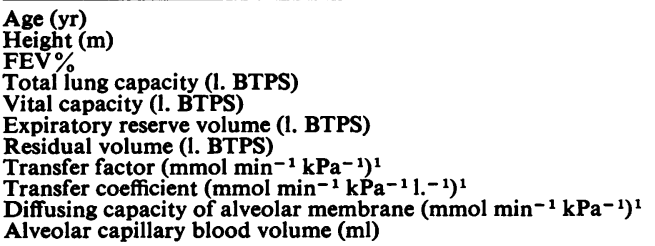 & $\begin{array}{l}46 \\
1 \cdot 68 \\
79 \\
5 \cdot 46 \\
3 \cdot 69 \\
1 \cdot 10 \\
1 \cdot 76 \\
9 \cdot 4^{2} \\
1 \cdot 8^{2} \\
16 \cdot 4^{2} \\
75\end{array}$ & $\begin{array}{l}50 \\
1 \cdot 68 \\
77 \\
5 \cdot 81 \\
3 \cdot 85 \\
1 \cdot 25 \\
1 \cdot 95 \\
9 \cdot 4 \\
1 \cdot 7 \\
17 \cdot 8 \\
69\end{array}$ & $\begin{array}{l}52 \\
1 \cdot 67 \\
59 \\
6 \cdot 20^{2} \\
3 \cdot 60^{2} \\
1 \cdot 51^{2} \\
2 \cdot 50^{2} \\
8 \cdot 0^{2} \\
1.4^{2} \\
18 \cdot 1^{4} \\
49\end{array}$ \\
\hline
\end{tabular}

${ }^{1}$ To convert to $\mathrm{ml} \mathrm{min}^{-1}$ torr $^{-1}$ multiply by $2 \cdot 986$.

standardized to mean age and height of smokers with an FEV $\%>65$.

$(3.7 \%)$ of the 614 women in the surveys complained of chronic phlegm. Two of the 23 were smokers. In contrast to the men, an $\mathrm{FEV} \%$ of 65 or below was found in 19 women non-smokers, five of whom were asthmatic with chronic phlegm, and in two women smokers.

CLINICAL STUDY Patients differed as a group from the survey population in a number of important respects. First, they were older, the average age being 62 (range 35-78) years. Second, all 36 male patients and five of the 11 female patients were either current smokers or ex-smokers. Third, in both sexes the ethnic composition differed markedly from that of the Jamaican population and also from that of the Kingston metropoliian area to which most patients belonged. Table $\mathrm{V}$ shows that among the patients European; and Indians were over-represented, Africans were under-represented, and people of mixed ancestry occupied an intermediate position. Fourth, the FEV $\%$ values were low (mean $38 \%$ and $47 \%$ for men and women respectively) and all patients complained of persistent breathlessness on exertion.

All but one of the 45 patients included in the analysis returned the container for sputum collection. There was a significant correlation between a positive response to the question 'Do you usually bring up any phlegm from your chest in the morning or during the day?' and the ability to provide a specimen of phlegm on the test day. Thus 21 of 25 positive responders to this question produced a specimen, compared with only five of the 20 negative responders $(P<0.005)$.

Eleven $(31 \%)$ male patients and all female patients considered themselves asthmatic insofar as each had experienced attacks of wheezing with
T A B L E V

DISTRIBUTION OF HOSPITAL PATIENTS BY ETHNIC GROUP AND BY RESIDENCE. ETHNIC COMPOSITION OF ALL ISLAND AND KINGSTON AND ST. ANDREW (KSA) POPULATIONS FOR COMPARISON ${ }^{1}$

\begin{tabular}{|c|c|c|c|c|c|c|}
\hline \multirow[b]{3}{*}{ Ethnic Group } & \multicolumn{3}{|c|}{ All Island } & \multicolumn{3}{|c|}{ KSA } \\
\hline & \multicolumn{2}{|c|}{ Patients } & \multirow{2}{*}{$\frac{\text { Census }}{\%}$} & \multicolumn{2}{|c|}{ Patients } & \multirow{2}{*}{$\frac{\text { Census }}{\%}$} \\
\hline & No. & $\%$ & & No. & $\%$ & \\
\hline $\begin{array}{l}\text { African } \\
\text { Mixed ancestry } \\
\text { European } \\
\text { Indian } \\
\text { Chinese } \\
\text { Other }\end{array}$ & $\begin{array}{r}20 \\
12 \\
10 \\
4 \\
1 \\
0\end{array}$ & $\begin{array}{r}43 \\
26 \\
21 \\
9 \\
2 \\
0\end{array}$ & $\begin{array}{l}78 \\
18 \\
0 \cdot 1 \\
0 \cdot 4 \\
0 \cdot 6 \\
2 \cdot 9\end{array}$ & $\begin{array}{r}14 \\
9 \\
9 \\
4 \\
0 \\
0\end{array}$ & $\begin{array}{r}39 \\
25 \\
25 \\
11 \\
0 \\
0\end{array}$ & $\begin{array}{l}60 \\
30 \\
1 \cdot 3 \\
1 \cdot 3 \\
1 \cdot 7 \\
5 \cdot 3\end{array}$ \\
\hline Total & 47 & 100 & $100 \cdot 0$ & 36 & 100 & $100 \cdot 0$ \\
\hline
\end{tabular}

${ }^{1}$ Department of Statistics, Kingston, Jamaica (1960). Census.

breathlessness. One of these men and seven of the women showed an improvement in lung function after isoprenaline inhalation. Only one of these eight patients (a woman) was a smoker, and in all, asthmatic attacks with recurrent or chronic bronchitis had begun at ages ranging from early childhood to 50 years. All 14 nonresponders to isoprenaline were smokers; four had had childhood asthma which declined in adulthood to be followed after 40 years of age by chronic breathlessness, and 10 developed episodic wheezing with breathlessness for the first time in adulthood. One woman and three men in this latter group of 10 were subsequently found to have extensive emphysema at necropsy, and two were brothers with familial emphysema.

There were 20 patients (17 smokers, 3 nonsmokers) without chronic phlegm and 25 with chronic phlegm (22 smokers, 3 non-smokers). When those without chronic phlegm were subdivided according to whether they noted episodic wheezing with breathlessness, no differences in 
the pattern of lung function were observed. Among patients with chronic phlegm those with episodic wheezing and breathlessness had as a group less severe airways obstruction, somewhat larger lung volumes, and a similar transfer coefficient to those without this symptom. Thus there was no evidence that 'asthma' was associated with any additional permanent impairment of lung function. The patients were therefore divided simply according to the presence or absence of chronic phlegm (Table VI). In order to allow for

\section{T A B L E V I}

AVERAGE LUNG VOLUMES AND GAS TRANSFER INDICES IN 45 PATIENTS WITH CHRONIC LUNG DISEASE AND AIRWAYS OBSTRUCTION, ACCORDING TO PRESENCE OBSTRUCTION, ACCORDING TO PR
OR ABSENCE OF CHRONIC PHLEGM

\begin{tabular}{|c|c|c|}
\hline \multirow[b]{2}{*}{ Index } & \multicolumn{2}{|c|}{ Chronic Phlegm } \\
\hline & Present & Absent \\
\hline $\begin{array}{l}\text { Number } \\
\text { Age (yr) } \\
\text { Patients with a history of smoking } \\
\text { Forced expiratory volume } \\
\text { Forced vital }\end{array}$ & $\begin{array}{l}25 \\
58 \\
22 \\
60\end{array}$ & $\begin{array}{l}20 \\
65 \\
17 \\
54\end{array}$ \\
\hline $\begin{array}{l}\text { Vital capacity (1. BTPS) } \\
\text { Functional residual capacity (1. BTPS) } \\
\text { Residual volume (1. BTPS) } \\
\text { Total lung capacity (1. BTPS) } \\
\text { Transfer factor (mmol min } \mathbf{m P a}^{-1} \text { ) } \\
\text { Transfer coefficient (mmol } \mathbf{m i n}^{-1} \mathbf{k P a}^{-1} 1^{-1} \text { ) } \\
\text { Diffusion capacity of alveolar membrane } \\
\left.\text { (mmol min-1 } \mathbf{k P a}^{-1}\right) \\
\text { Alveolar capillary blood volume (ml) }\end{array}$ & $\begin{array}{r}75 \\
139 \\
186 \\
111 \\
68 \\
66 \\
67 \\
52\end{array}$ & $\begin{array}{r}77 \\
141 \\
182 \\
117 \\
64 \\
57 \\
63 \\
44\end{array}$ \\
\hline
\end{tabular}

All results except alveolar capillary blood volume are presented as a percentage of expected average normal values, age and height adjusted. For Europeans see Cotes (1968). Normal values for Africans and Indians are those found for healthy non-smokers in Jamaica.

differences in lung function which exist between sexes and ethnic groups the results have been expressed as a percentage of predicted normal values, and Indians have been considered as having similar lung volumes and gas transfer indices to Africans (Edwards, Miller, Hearn, and Cotes, 1972). Both subgroups had a comparable degree of airways obstruction, a similar increase in total lung capacity and residual volume, and a similar reduction in all gas transfer indices including the diffusion capacity of the alveolar membrane. In both subgroups the radiographic estimate of total lung capacity (Barnhard, Pierce, Joyce, and Bates, 1960) agreed to within $4 \%$ on average of that given by helium dilution.

As a group the six female non-smoking patients with airways obstruction partly responsive to isoprenaline differed from smokers in having a normal transfer factor (mean 6.2, compared with predicted mean of $6.4 \mathrm{mmol} \mathrm{min}{ }^{-1} \mathrm{kPa}^{-1}$ ) and a normal alveolar capillary blood volume (mean $65 \mathrm{ml}$ ).
Six of the 47 patients died from their lung disease during the course of this study and in each case necropsy information was obtained. Two were brothers with familial emphysema. The remaining four (one female) were also found to have extensive destructive emphysema. No necropsy reports were obtained for two other patients who died, one in a road accident and another from carcinoma rectum.

\section{DISCUSSION}

A great variety of both local and imported tobaccos is available in both Jamaica and Guyana. Cigarettes, cigars, leaf tobacco, and 'twist' or 'rope' are all produced on a commercial scale from local crops and many people cultivate and cure their own leaf for personal consumption.

The great majority of smokers in these surveys were regular users of the ordinary manufactured cigarette although some had also smoked other varieties of tobacco from time to time. Unfortunately questions were not asked about the use of filter cigarettes and the interviewer considered that the responses to questions about inhalation were frequently unreliable.

At the present time cigarette smoking appears to be the major cause of chronic cough and phlegm in the West Indies. Less chronic lung disease occurs in this region than in temperate and industrialized areas such as Staveley, partly because cigarette consumption is lower and partly because the air and climate of the West Indies is more conducive to respiratory health (Pan American Health Organization, 1971). In the UK, Holland, Halil, Bennett, and Elliott (1969) have suggested that exposure to some environmental factors in childhood, including atmospheric pollution, contributed to the development of chronic respiratory disease in later years. This might explain why young non-smokers in Staveley had more chronic phlegm and a lower FEV \% than non-smokers of similar age in the West Indies. In addition, and as discussed later, there is some evidence that subjects of African origin (who form the majority in the West Indies) are less susceptible to the respiratory effects of cigarette smoke than other ethnic groups.

The FEV \% was chosen in preference to the FEV $_{1}$ or FVC as an index of airways obstruction for two reasons. First, being a ratio of two volumes, the FEV\% has no dimensions and is not therefore influenced by ethnic differences in lung volumes (Edwards, Miller, Hearn, and Cotes, 1972). Second, the FEV $\%$ is better 
correlated with the rate of development of airways obstruction than is either of its component values (Fletcher, Peto, Speizer, and Tinker, 1969). In the absence of smoking the decline in FEV\% with age in the West Indian men appeared trivial. For male smokers and non-smokers combined the linear regression was:

$$
\text { FEV } \%=87-0.12 \text { age (years) (RSD, 6.1) }
$$

Thus only $2.5 \%$ of men at age 65 years would be expected to have an FEV \% of less than $67 \%$ (that is, less than 2 RSD below the mean). On this account the acceptance of an FEV\% of 65 or less after isoprenaline inhalation as evidence of irreversible airways obstruction seemed reasonable for men in Jamaica and Guyana, and was supported by its associations with other lung function disturbances (Table IV). For women in the West Indies, most of whom were non-smokers, the decline in $\mathrm{FEV} \%$ with age was larger than that for the men:

$$
\text { FEV } \%=87-0.16 \text { age (years) (RSD, 7.8) }
$$

Why this should be was not apparent from the data but it probably explained the presence of an FEV \% of less than 65 in 14 apparently healthy female non-smokers, and suggested that an FEV\% of 65 afforded less evidence of respiratory disease in women than in men in the West Indies.

In most respects the lung function changes associated with tobacco smoking resembled those reported from the UK and the United States. Krumholz and Hedrick (1973) found a reduced FEV \% and an increased residual volume and functional residual capacity in middle-aged smokers compared with non-smokers. In addition, they and also van Ganse, Ferris, and Cotes (1972) reported a reduction in the transfer coefficient of smokers which the latter group showed to be due to a reduction in the alveolar capillary blood volume. There is some disagreement over changes in total lung capacity in smokers. Krumholz and Hedrick (1973) found a very small reduction in smokers, but, as in the present study, C. E. Rossiter (personal communication) found an increase in total lung capacity in smokers compared with non-smokers in a survey of asbestos cement workers who were minimally exposed to asbestos dust (no cough, phlegm, breathlessness and no chest radiograph changes). Also, McFadden and Linden (1972) found the mean total lung capacity increased to $108 \%$ of predicted average normal in a group of patients with heavy smoking histories and mild airways obstruction, though they did not consider this change significant.
In the West Indies the majority of smokers appear to maintain a normal vital capacity and diffusion capacity of the alveolar membrane (see Table IV), at least until the seventh decade. The reductions in ventilatory capacity and transfer coefficient associated with smoking are in the great majority not sufficient to produce a degree of breathlessness which makes the smoker seek medical advice. However, the hospital series indicated that in a small number of smokers the lung lesion does progress to a stage where ventilatory capacity, the diffusion capacity of the alveolar membrane, and the transfer coefficient are markedly reduced and breathlessness is considerably increased. Bronchial hypersecretion, although frequently present, does not apparently contribute to this decline in lung function since, as shown in Table VI, there was no apparent difference between the lung function of those patients with chronic phlegm and those without this symptom. A real difference in sputum production probably existed in the two groups, as shown by the difference in sputum volumes collected during the first hour of the morning.

Regarding the pathological basis of the reduction in transfer coefficient in smokers, Burrows and colleagues (1964) found that when patients with chronic lung disease in London and Chicago were divided into an emphysema group, a chronic inflammatory group, and an intermediate group, according to the chest radiograph, the emphysema group but not the chronic inflammatory group had a reduction in the transfer coefficient. Teculescu, Racoveanu, and Manicatide (1973) classified patients with chronic obstructive lung disease into bronchitic, emphysematous, and intermediate subgroups according to the criteria of Nash, Briscoe, and Cournand (1965) and found a mean transfer coefficient $60 \%$ of predicted normal in the emphysema group compared with $88 \%$ of predicted normal in the bronchitic group. One hundred and thirty-one of the 137 patients in these two studies were smokers. Among both survey subjects and hospital patients in Jamaica, smoking was associated with a reduction in the transfer coefficient, whether or not chronic bronchitis was present. This suggested that in the West Indies at least most of the chronic airways obstruction of smokers was due to emphysema.

It is of interest to compare the $\mathbf{3 4}$ male patients in Jamaica with the group of 100 patients selected by Burrows and colleagues (1964) as being representative of hospital experience in London and Chicago. Table VII shows that both groups were 


\section{T A B L E V I I}

COMPARISON OF MALE PATIENTS WITH CHRONIC LUNG DISEASE AND AIRWAYS OBSTRUCTION IN LONDON AND CHICAGO (BURROWS et al., 1964), AND IN JAMAICA

\begin{tabular}{|c|c|c|}
\hline & $\begin{array}{l}\text { London/ } \\
\text { Chicago }^{1}\end{array}$ & Jamaica $^{2}$ \\
\hline 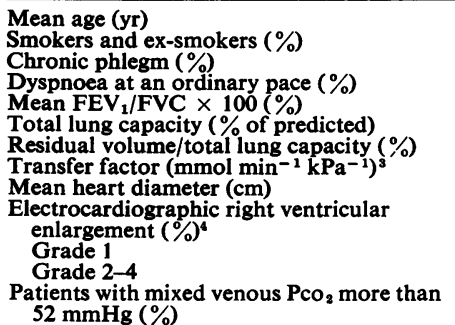 & $\begin{array}{l}58 \cdot 3 \\
99 \\
85 \\
87 \\
35 \\
119 \\
60 \\
6 \cdot 3 \\
12 \cdot 5 \\
\\
23 \\
18 \\
26\end{array}$ & $\begin{array}{c}61 \cdot 5 \\
100 \\
53 \\
79 \\
38 \\
111 \\
61 \\
5 \cdot 4 \\
13 \cdot 7 \\
\\
26 \\
29 \\
9\end{array}$ \\
\hline
\end{tabular}

150 London patients and 50 Chicago patients.

234 patients.

${ }^{3}$ To convert to $\mathrm{ml} \mathrm{min}^{-1}$ torr $^{-1}$ multiply by $2 \cdot 986$.

'Classification of Goodwin and Abdin (1959).

similar with regard to age, smoking habits, and degree of airways obstruction (FEV\%). In addition, a similar proportion of each group noted breathlessness when walking at an ordinary pace on the level. Total lung capacity and residual volume as a fraction of total lung capacity were increased in both groups and gas transfer was reduced by similar amounts. Despite these similarities, however, the Jamaican group had considerably less evidence of chronic bronchitis both subjectively according to the complaint of chronic phlegm and objectively according to the proportion with hypercapnia. This difference agreed with the survey finding of less cough and phlegm among smokers in the West Indies than the UK, and similarly was probably related to the healthier air and climate of Jamaica. The results of sputum collection in the first hour after rising were evidence for the validity of the response to the questionnaire in that patients who stated that they usually coughed up phlegm were usually able to produce a morning specimen, whereas those who stated that they did not usually have phlegm were usually unable to produce a specimen. The apparently comparable amounts of right ventricular involvement in the two series suggested that hypoxia (Hasleton, Heath, and Brewer, 1968) was as prevalent among Jamaican patients as among patients in the UK and North America, and supported the necropsy finding of Stuart and Hayes (1963) that in Jamaica right ventricular enlargement was commonly secondary to lung disease.

While the post-mortem emphysema found in Jamaica by Hayes and Summerell (1969) was probably associated with cigarette smoking, Hayes had insufficient information about smoking habits to confirm this (Hayes, 1970). However, Ryder, Dunnill, and Anderson (1971) in the UK, and Auerbach, Hammond, Garfinkel, and Benante (1972) in the USA have reported strong relationships between emphysema at death and tobacco smoking during life, and extensive emphysema was found in all six smokers who came to necropsy during the course of the present study.

The Guyana survey (Miller and Ashcroft, 1971) showed that chronic bronchitis was less common among Africans than among Indians, a co difference which was not accounted for by differences in smoking habits and occupation. In the present study, Africans were similarly under- $\omega$ represented in the Jamaican hospital series while Europeans and Indians were over-represented. Again, the occupational and smoking histories offered no explanation for these differences. It was unlikely that this difference was due to a bias $\vec{\theta}$ in hospital admissions because the ethnic com- $\perp$ position of cancer deaths at the University 0 Hospital over this period resembled that of the general community. Thus $76 \%$ of lung cancers at necropsy were among Africans, and only $8 \%$ were among Europeans (Bras, Whimster, Patrick, and Woo-Ming, 1972). The evidence was therefore that men of African origin in the West Indies were less susceptible to the emphysema effect of cigarette smoking than men of other ethnic groups. A similar impression has been gained in North America by Murphy, Katz, Massaro, and $\bar{\partial}$ Luchsinger (1962), and in New York City Stebbings (1973) found a significantly smaller decline in FEV $_{1}$ with age among coloured male $\underline{3}$. smokers as compared with white smokers, while 8 among non-smokers the rate of decline with age $₹$ appeared similar in the two ethnic groups.

The basis of this apparent ethnic difference in susceptibility to chronic lung disease is unknown. Long-term cigarette smoking is known to increase the peripheral blood leucocyte independently of $\sigma$ chronic bronchitis (Corre, Lellouch, and $N$ Schwartz, 1971) and also to increase the alveolar $\mathrm{W}^{\mathrm{N}}$ leucocyte count (Rylander, 1971). Friedman 0 et al. (1973) have shown that the leucocyte re-o sponse to smoking is less marked in subjects of $\frac{\mathscr{D}}{\mathbb{D}}$ African origin than in those of European or $\stackrel{\oplus}{?}$ Chinese ancestry. On this account Africans may 0 have less emphysema than other ethnic groups

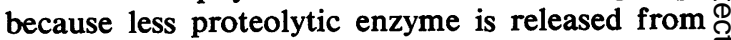
leucocytes (Tarkoff, Kueppers, and Miller, 1968) $\overrightarrow{\mathbb{D}}$ into the pulmonary tissues during smoking.

The hospital series showed that in the West 
Indies irreversible airways obstruction also occurred in the occasional non-smoker who was an asthmatic. However, in these patients airways obstruction was not associated with a defect of pulmonary gas transfer, at least when the asthma was in remission. Other conditions considered as possible causes of airways obstruction were the lipoid pneumonia of blackfat tobacco smokers (Miller et al., 1971) and tropical pulmonary eosinophilia. The latter disease has been reported as causing airways obstruction in Ceylon (Nesarajah, 1972) but not in India (Azad Khan, Patra, Banu, and Rabbee, 1970). Both conditions occur in Guyana, but since neither is recognized in Jamaica they could not have contributed to the symptoms and lung function found to be associated with ordinary tobacco smoking in this study.

In summary, most smokers of ordinary tobacco in the West Indies note little more than a tendency to cough for more than 30 years after acquiring the habit. During this time the reduction in ventilatory capacity and gas transfer is not sufficient to produce a clinical grade of breathlessness. In a minority, however, damage to the peripheral architecture of the lung (probably emphysematous change) eventually reaches critical proportions and breathlessness increases. This process is accelerated in the presence of $\alpha_{1}$-antitrypsin deficiency, as was the case with two brothers in the hospital series who had severe emphysema by their fourth decade. At present chronic bronchitis does not appear to play an important role in the aetiology of airways obstruction in this part of the world.

I wish to thank Dr. W. E. Miall and Dr. J. E. Cotes for their encouragement and advice. Professor A. G. Heppleston kindly arranged for serum $\alpha_{1}$-antitrypsin studies on two patients with familial emphysema and Dr. W. F. Whimster provided the whole-lung sections. Mr. M. J. Saunders gave technical advice and Mr. T. J. Cole provided statistical assistance. The work of the field staff of the Medical Research Council Epidemiology Unit, Jamaica is also gratefully acknowledged.

\section{REFERENCES}

Auerbach, O., Hammond, E. C., Garfinkel, L., and Benante, C. (1972). Relation of smoking and age to emphysema. New England Journal of Medicine, 286, 853.

Azad Khan, A. K., Patra, R. W. T., Banu, S. A., and Rabbee, M. F. (1970). Spirometry in tropical pulmonary eosinophilia. British Journal of Diseases of the Chest, 64, 107.
Barnhard, H. J., Pierce, J. A., Joyce, J. W., and Bates, J. H. (1960). Roentgenographic determination of total lung capacity. American Journal of Medicine, 28, 51.

Bras, G., Whimster, W. F., Patrick, A. L., and Woo-Ming, M. (1972). Aspects of lung cancer in Jamaica. Cancer, 29, 1590.

Burrows, B., Niden, A. H., Fletcher, C. M., and Jones, N. L. (1964). Clinical types of chronic obstructive lung disease in London and in Chicago. American Review of Respiratory Diseases, 90, 14.

Campbell, E. J. M. and Howell, J. B. L. (1962). Rebreathing method for measurement of mixed venous $\mathrm{pCO}_{2}$. British Medical Journal, 2, 630.

Collins, M. M., McDermott, M., and McDermott, T. J. (1964). Bellows spirometer and transistor timer for the measurement of forced expiratory volume and vital capacity. Journal of Physiology, 172, 39P.

Corre, F., Lellouch, J., and Schwartz, D. (1971). Smoking and leucocyte counts. Lancet, $2,632$.

Cotes, J. E. (1968). Lung Function: Assessment and Application in Medicine, 2nd ed. Blackwell Scientific Publications, Oxford.

Dabbs, J. M., Elwood, P. C., Hall, A. M., McDonald, A., and Saunders, M. J. (1972). Irondeficiency anaemia: its effect on transfer factor for the lung (diffusing capacity) and ventilation and cardiac frequency during submaximal exercise. Clinical Science, 42, 325.

Department of Statistics, Kingston, Jamaica (1960). Census of Jamaica.

Edwards, R. H. T., Miller, G. J., Hearn, C. E. D., and Cotes, J. E. (1972). Pulmonary function and exercise responses in relation to body composition and ethnic origin in Trinidadian males. Proceedings of the Royal Society of London, Series $B, \mathbf{1 8 1}, 407$.

Fletcher, C. M., Peto, R., Speizer, F. S., and Tinker, C. M. (1969). A follow-up study of the natural history of chronic bronchitis. Proceedings of the Third International Symposium on Bronchitis, edited by N. G. M. Orie and R. van de Lende, p. 103. Royal Vangorcum, Assen.

Friedman, G. D., Siegelaub, A. B., Seltzer, C. C., Feldman, R., and Collen, M. F. (1973). Smoking habits and the leucocyte count. Archives of Environmental Health, 26, 137.

Goodwin, J. F. and Abdin, Z. H. (1959). The cardiogram of congenital and acquired right ventricular hypertrophy. British Heart Journal, 21, 523.

Hasleton, P. S., Heath, D., and Brewer, D. B. (1968). Hypertensive pulmonary vascular disease in states of chronic hypoxia. Journal of Pathology and Bacteriology, 95, 431.

Hayes, J. A. (1970). Racial, occupational, and environmental factors in relation to emphysema in Jamaica. Chest, 57, 136.

and Summerell, J. M. (1969). Emphysema in a non-industrialized tropical island. Thorax, 24, 623. 
Higgins, I. T. T. and Cochrane, A. L. (1961). Chronic respiratory disease in a random sample of men and women in the Rhondda Fach in 1958. British Journal of Industrial Medicine, 18, 93.

, Gilson, J. C., Ferris, B. G., Waters, M. E., Campbell, H., and Higgins, M. W. (1968). Chronic respiratory disease in an industrial town: a nineyear follow-up study. Preliminary report. American Journal of Public Health, 58, 1667.

Holland, W. W., Halil, T., Bennett, A. E., and Elliott, A. (1969). Factors influencing the onset of chronic respiratory disease. British Medical Journal, 2, 205.

- and Reid, D. D. (1965). The urban factor in chronic bronchitis. Lancet, 1, 445.

Krumholz, R. A. and Hedrick, E. C. (1973). Pulmonary function differences in normal smoking and non-smoking, middle-aged, white-collar workers. American Review of Respiratory Disease, 107, 225.

McFadden, E. R. and Linden, D. A. (1972). A reduction in maximum mid-expiratory flow rate. A spirographic manifestation of small airway disease. American Journal of Medicine, 52, 725.

Meade, F., Saunders, M. J., Hyett, F., Reynolds, J. A., Pearl, N., and Cotes, J. E. (1965). Automatic measurement of lung function. Lancet, $2,573$.

Miller, G. J. and Ashcroft, M. T. (1971). A community survey of respiratory disease among East Indians and African adults in Guyana. Thorax, 26, 331.

- $\longrightarrow$, Beadnell, H. M. S. G., Wagner, J. C., and Pepys, J. (1971). The lipoid pneumonia of blackfat tobacco smokers in Guyana. Quarterly Journal of Medicine, N.S., 40, 457.

—, Cotes, J. E., Hall, A. M., Salvosa, C. B., and Ashworth, A. (1972). Lung function and exercise performance of healthy Caribbean men and women of African ethnic origin. Quarterly Journal of Experimental Physiology, 57, 325.

Murphy, R. E., Katz, S., Massaro, D. J., and Luchsinger, P. C. (1962). Is emphysema a disease predominantly of the white male? Journal of the American Medical Association, 181, 726.

Nash, E. S., Briscoe, W. A., and Cournand, A. (1965). The relationship between clinical and physiological findings in chronic obstructive disease of the lungs. Medicina Thoracis, 22, 305.

Nesarajah, M. S. (1972). Pulmonary function in tropical eosinophilia. Thorax, 27, 185.
Ogilvie, C. M., Forster, R. E., Blakemore, W. S. and Morton, J. W. (1957). A standardized breath-holding technique for the clinicals measurement of the diffusing capacity of the lung for carbon monoxide. Journal of Clinical Investigation, 36, 1.

Pan American Health Organization (1971). Depart $\overrightarrow{0}$ ment of Engineering and EnvironmentalSciences. Pan American Air Pollution Monitor $\vec{w}$ ing Network, June, 1967-December, 1970.9 CEPIS, Lima.

Report of the Surgeon General (1972). The Healthin Consequences of Smoking. US Department of: Health, Education and Welfare. US Government Printing Office, Washington.

Ryder, R. C., Dunnill, M. S., and Anderson, J. A (1971). A quantitative study of bronchials mucous gland volume, emphysema and smoking in a necropsy population. Journal of Pathology, 104, 59.

Rylander, R. (1971). Free lung cell studies in cigarette $\frac{\overrightarrow{\mathbb{D}}}{3}$ smoke inhalation experiments. Scandinavian Journal of Respiratory Disease, 52, 121.

Stebbings, J. H. (1973). A survey of respiratory $\vec{c}$ disease among New York City postal and transit workers. IV. Racial differences in the FEV . Environmental Research, 6, 147.

Stuart, K. L. and Hayes, J. A. (1963). A cardiac dis order of unknown aetiology in Jamaica. Quarterly Journal of Medicine, 32, 99.

Tarkoff, M. P., Kueppers, F., and Miller, W. F. (1968). Pulmonary emphysema and alpha $a_{1}$-antitrypsin deficiency. American Journal ofo Medicine, 45, 220.

Teculescu, D. B., Racoveanu, C., and Manicatide, M. M. (1973). Transfer factor for the lung and? 'emphysema score'. Respiration, 30, 311.

Tobacco Research Council (1969). Statistics of smok-으 ing in the United Kingdom. Research Paper $1, \mathbb{x}$ 5 th ed., edited by G. F. Todd.

van Ganse, W. F., Ferris, B. G., and Cotes, J. Eב (1972). Cigarette smoking and pulmonaryi diffusing capacity. American Review of Respiratory Disease, 105, 30.

Requests for reprints to: G. J. Miller, Medical Research Council Pneumoconiosis Unit, Llandough Hospital, Penarth, Glamorgan, S. Wales. 